\title{
LISTOF CONTRIBUTORS
}

JOHN M. MACKENZIE is Professor of Imperial History and Dean of Humanities at Lancaster University. He is the author of Propaganda and Empire and The Empire of Nature, and editor of Imperialism and Popular Culture and Imperialism and the Natural World.

ROBERT GIDDINGS is a member of the Department of Communication and Media Studies at Bournemouth Polytechnic. Among his books are Musical Quotations and Anecdotes and The War Poets, 1914-19. He has recently edited a volume of essays entitled Literature and Imperialism.

DAVE RUSSELL is Senior Lecturer in the School of Historical and Critical Studies at Lancashire Polytechnic; he has published widely in the area of popular culture and is the author of Popular Music in England, 1840-1914.

JEFFREY RICHARDS is Professor of Cultural History at Lancaster University. Among his books are The Age of the Dream Palace, Happiest Days and (as editor) Imperialism and Juvenile Literature. He writes for the Daily Telegraph and is a frequent broadcaster on BBC Radio.

ROGER STEARN is head of history at Loughton College. His PhD was on ' War Images and Image Makers in the Victorian Era: Aspects of the British Visual and Written Portrayal of War, c. 1866-1906' and he has published a number of articles on Victorian military artists, on H. G. Wells and on war correspondents.

PAUL USHERWOOD is a member of the Department of Historical and Critical Studies at Newcastle upon Tyne Polytechnic; he is the joint author of Lady Butler (1846-1933) - Battle Painter, which won the National Heritage Museum of the Year Publication Award in 1988, and of several articles on Lady Butler and other Victorian artists.

DAVID MAYER is Reader in Drama at Manchester University and is the author of Harlequin in his Element: English Pantomime, 1806-36 and (with Kenneth Richards) Western Popular Theatre. He has written about the music of Victorian melodramas, has published many articles on theatrical history and has edited several play texts.

DAVID OMISSI is a research fellow at Nuffield College, Oxford, and the author of Air Power and Colonial Control: the Royal Air Force 1919-39, and of several articles on colonial military history. He is currently working on a study of the army in British India. 